\title{
Study on the Credit-based System with Chinese Characteristics from the Perspective of System Analysis*
}

\author{
Jiaming Sun \\ School of Education \\ South China Normal University \\ Guangzhou, China
}

\begin{abstract}
There are two kinds of disputes in the creditbased system with Chinese characteristics: namely the theory of transition and the theory of innovation. Through the analysis from the institutional level, this system is the rational choice and institutional innovation of the college teaching management system in the transitional period, or a temporary equilibrium in the supply and demand of the institutional structure, of which the reason is that the reality of China's national conditions, social economy, education mode and educational resources determine the state of institutional equilibrium. Under the formal institutional framework, the exploration of the system innovation of the credit-based system in China from the five aspects of independent choice + limited choice, class tutor system + system of counselors, class teaching system + course class system, professional registration fee system + course credit fee system and the credit authentication system + credit transfer system is helpful to construct the teaching management system of modern university in our country and promote the "chain effect" in the reform of the internal system of colleges and universities.
\end{abstract}

Keywords-credit-based system; contention focus; basis of reality; system innovation

\section{INTRODUCTION}

Throughout the institutional changes of the credit system reform in colleges and universities in China, we have formed the credit-based system in most colleges and universities after a series of "localization" attempts (including complete credit system, plan credit system, credit-based system, comprehensive weighted credit system, compound credit system, special zone credit system and credit system+ flexible educational system, etc. $)^{[1]}$. The Outline of the National Medium and Long-Term Plan for Reform and Development of Education (2010-2020) proposes to "deepen the teaching reform, promote and improve the credit system." But the reform of the credit-based system should not blindly follow the fashionable mentality of "the foreign countries are all based on the credit system" "other colleges

*Fund project: Guangdong province 2015 advanced education and teaching reform project (No.: comprehensive class 545); Guangdong province 2017 key platform and scientific research project - Special innovation project (education and scientific research)(No. : 2017GXJK158). and universities also carry out credit system" and so on, also should not one-sided to negate the credit-based system. The author thinks that, from the perspective of institutional analysis, the key question is how to reform, especially under the basic condition of our country, and how to combine the scholastic year system with the credit system to create the credit system of Chinese characteristics.

\section{CREDIT-BASED SYSTEM WITH CHINESE} CHARACTERISTICS: TRANSITION OR INNOVATION?

Through retrieving the CNKI database using the subject and title "Credit-Based System", from January 1, 1979 August 31, 2017, there are 89 research papers exclusive of the duplicates, which mainly discuss the advantages and disadvantages of the credit-based system from the perspectives of experience introduction, mode comparison, restriction factor, case analysis, etc. These representative studies are conducive to the in-depth study of the change of the credit system of Chinese universities as "Chinese university" rather than "in", however, it also shows that there is a lack of theoretical study for the system attribute, realistic foundation and institutional innovation of the credit-based system. In a word, there are two main arguments for the credit-based system with Chinese characteristics:

\section{A. The Transition Theory}

This thesis argues that the credit-based system is the primary form of transition from the scholastic year system to the credit system, which is still considered as the scholastic year system ${ }^{[2]}$, which focuses on the negative evaluation to the credit-based system. It is believed that the credit-based system with Chinese characteristics started in the 1980s, which is the product of the transition from the planned economy to the market economy in China. With the gradual improvement of China's socialist market economy system and the matching reforms such as the political system reform, colleges and universities in China will also implement the corresponding credit system which is dominated by the market. The current credit-based system is inconsistent with the modern university management system, which has three reasons: first, the teaching management system based on the school year, school (department) and major is too rigid and 
lack elasticity; second, it is still a uniform education mode which is in contradiction with individualized education mode of the students, who has no required autonomy and choice; third, it conflicts with the future employment needs, in the event of the increase of the diversification and selectivity in graduate employment as well as the slow implementation of internal major transfer, credit charging system, tutorial system and flexible educational system, etc., the credit-based system is difficult to meet the requirements of graduates' start-up and job market. Therefore, the credit-based system is only a kind of harmonic form of traditional scholastic year system and credit system, which has not broken through the scholastic year system, so it is unable to adapt to the reform requirements of the new era teaching management system and will be inevitably be replaced by the credit system. Therefore, it is concluded that "the credit-based system is a stage of the development of the credit system" ${ }^{[3]}$.

\section{B. The Innovation Theory}

This thesis mainly focuses on the affirmative evaluation to the credit-based system, which believes that the creditbased system combined the main characteristics of both the scholastic year system and the credit system which can complement each other. It can also be considered to be the result of "localization" that combined the western developed countries' university credit system with China's national conditions. Therefore, it is a teaching management system of "a credit system with Chinese characteristics" ${ }^{[4]}$. The main institutional innovation of the credit-based system is mainly shown in four aspects: first, the implementation of "school year + credit". The main body of the credit-based system is still the scholastic year system, in general, the length of schooling of undergraduate students is 4-8 years, and that of the junior college students is 3-6 years. Each course has a specified amount of credits, but the real measure of students' academic performance is the number of hours that students study. Second, implementation of "course module + elective course", each major can be divided into several professional emphasis according to the need, which forms course modules of different professional emphasis. Students must complete the required course of the module as long as they choose a certain professional direction. Meanwhile, they should take elective courses according to individual learning preference and complete the highest and lowest credit limits. Third, the implementation of "make-up examination + restudy", in the credit-based system, each course has corresponding terms and credit hours, and a unified examination at the end of the term. Because a single test does not fully examine the student's learning results, so the students can take a make-up exam if they fail the exam, but they must restudy it if they fail the make-up exam. Fourth, the implementation of "credit + GPA", credit is the computing unit of the amount of study hours, but it is difficult for it to judge the quality of the study, so the Credit \& Accumulated-points System is adopted. GPA is the weighted average of the arithmetic product of the student credit and score, and the GPA is adopted as the evaluation criteria of the exemption, awards, early graduation, degrees conferred, etc.
Thus it can be seen that the "transition theory" is mainly focused on the negative evaluation to the system vicissitude, which believes that the credit-based system will be "revolutionized" by social development and education reality; while the "innovation theory" is mainly focused on the affirmative evaluation to the system vicissitude, which believes that it is necessary to innovate the teaching management system according to specific time and site based on the credit-based system. The focus of the debate is a kind of "metaphysical" thinking, namely the "absolutely incompatible opposition" ${ }^{[5]}$. Therefore, the judgment standard on the credit-based system is confined to the opposite scope of "good" and "bad", "advantages" and "disadvantages", etc. it is believed from the perspective of institutional analysis that the credit-based system is essentially a teaching management system, of which the socalled "good" and "bad", "advantages" and "disadvantages" shall be considered as a whole, "There is no absolute advantage without disadvantage and absolute disadvantage without advantage in any system.,"[6] Secondly, the understanding of institutional change mode is biased. The way of institutional change is varied, and the gradual institutional change argues that "the system is gradually changed, not abruptly." ${ }^{[7]}$ The credit-based system with Chinese characteristics is not the rootless "duckweed"; it has a realistic social foundation for its generation, development and change. Therefore, the credit-based system with Chinese characteristics is the rational choice and institutional innovation of the transitional teaching management system, or the temporary equilibrium of the supply and demand of the institutional structure.

\section{THE CREDIT-BASED SYSTEM WITH CHINESE CHARACTERISTICS: REALISTIC BASIS}

According to the new institutional economics, institutional choice and institutional change can also be analyzed using the classical theoretical framework of "demand-supply". Since the system has changing demand and supply, there must be the equilibrium and disequilibrium of the system. The credit-based system with Chinese characteristics is an institutional structure composed of many systems. The realistic system restriction determined and established the state of system equilibrium. Therefore, it is not so much that the credit-based system with Chinese characteristics is the product of the system change of the process of credit system Chinese localization, but rather the institutional structure formed in the process from transplanting and imitation (mainly the United States, the Soviet union, etc.) gradually to localization. Through reviewing the disputes over the advantages and disadvantages, truth and falseness, and completeness or incompleteness of the credit-based system in reality, the reason lies in the fact that there is no analysis of the realistic foundation and system restriction of the credit-based system with Chinese characteristics. 
A. The Teaching Management System Should Serve the Construction of Socialist Cause Based on the Socialist National Conditions

Franz·F.Van Vught believes that there are two main traditions in the relationship between universities and governments: national control mode and national supervision mode ${ }^{[8]}$. China belongs to the former mode, which is mainly related to the nature of the socialist regime in China. Therefore, universities should adhere to the direction of socialist education. They must serve the socialist modernization and must combine with productive Labor and train the socialist cause builders and successors who have developed morally, intellectually and physically. It is necessary for the credit-based system with Chinese characteristics to ensure that the national curriculums are uniformly set up, and that the courses such as the course of the theory of Marxism and Leninism and the course of ideological morality are listed into the curriculum, compiled into the teaching materials and well learned by the students, and ensure that the students can study other national curriculums and be able to give attention to the study of other subjects and major courses, such as professional study and social practice.

\section{B. Based on the Actual Social Economy Situation, Teaching Management System Shall Adapt to the Developing Stage of Socialism}

The choice of college teaching management system is subject to the "elements of political and economic analysis". Although in a new era, the socialism with Chinese characteristics is still in the primary stage of socialism, and the social labor market is still improving. And there still exists blindness and spontaneity in the demand of each professional fields and the number of talents, for which the most colleges' admission plans, major setting and school funding are mainly allocated by the state according to the social and economic development. At present, China's colleges are in the transition from "government guidance to run a school" to "universities of autonomous management ". While the credit system is based on the universities of autonomous management, and the marketability of credit system management will have friction with the planning of administration of higher education. The choice of the creditbased system model with Chinese characteristics not only embodies the planning of talent training but also adapts to the needs of market regulation. Above all, the most important thing for the colleges is to combine students' personal preferences with national needs and social needs and to provide diversified talents and serve the national economic construction and social development.

\section{Based on the Actual Educational Pattern, Teaching Management System Shall Be Depended on Professional Education Modes}

The credit-based system with Chinese characteristics has certain existence value, which is a realistic choice under the premise that the mode of professional education has not changed. First, the enrollment system in accordance with majors (categories) has not yet been reformed. For a long time in China, first candidates fill in the forms of university and major, and then colleges carry out the admission by scores according to the enrollment plan. This kind of enrollment system, guided by professional education values, does not offer the choice rights of majors to students. And the free transfer of department and the transfer of major are also restricted. Second, the number of studying years by independent choice still needs to be overcome. The purpose of credit system reform is not to let students graduate in advance but to enable students to gain more autonomy and selectivity. But advancing or delaying graduation increases the complexity of teaching management, which also adds obstacles to graduates entering the social labor market, so most students still graduate according to the original stipulation. Third, the cohesive mechanisms between different types of universities and different levels of academic educations have not been fully realized, which results the difficult achievement of the mutual recognition of credit and converting system temporarily. Fourth, according to the Interim Measures on Charge Management of Colleges and Universities, the tuition fees for schools of different regions, majors and levels can be distinguished. But the examination and approval authority for tuition fees within the scope prescribed by the state is governed by provincial governments. This unified charging system makes it difficult to realize the foreign credit charging system in China.

\section{Based on the Actual School-running Resources, \\ Teaching Management System Shall Follow the Educational Teaching Law}

The system function of credit system is "to provide a guarantee of the main position of students in teaching activities." which is realized by "students' independent selection mechanism under the flexible teaching plan". If the educational resources conditions such as persons, money and materials are not mature in the reform of the credit system, we should not violate the law of education and teaching to put it into force. First, to deal with the contradiction between the independent choice of learning courses and the provision of rich and high-quality course resources. For example, the best universities in China can provide students with 1800 to 3000 courses. The best universities in the United States can provide five thousand or six thousand or even over ten thousands courses ${ }^{[10]}$. Second, to deal with the contradiction between the independent selection of teachers and the promotion of the number of teachers and the teaching quality. However, the proportions of teachers and students in some universities have exceeded the limit of $1: 18$, which is difficult to meet the requirements of university students' freely choosing teachers. Third, to deal with the contradiction between the independent choice of majors and the low proportion of major transfer. For example, at present the university with the most majors in China (Guizhou University) has 137 undergraduate majors. While there were only 83 persons choosing the transfer of major in the college in the school year of 2016-2017, and the proportion of freely choosing major is relatively low ${ }^{[11]}$; Fourth, to handle the contradiction between choosing your learning progress independently and the shortage of modern teaching ancillary resources. Some colleges and universities are in the 
overloading stage of the popularization of higher education. The average number of teaching administrative rooms and teaching and research instruments and equipment, books and other teaching resources for each student cannot better meet the requirements of college students' autonomous learning. Therefore, whether to implement the credit system shall be determined according to the nature and specific circumstances of universities. We shall not in a hurry to push it forward. ${ }^{[12]}$ The credit-based system with Chinese characteristics shall be adapted to each college's condition.

It is shown in the above analysis that the implementation of credit system does not mean the end of credit-based system. There is no unified mode in the world, nor is it necessary to change all credit-based systems into credit systems. It shall be clear that the most fundamental purpose of establishing a teaching management system is to improve the quality of teaching and learning, and it is beneficial to cultivate talents with diversity and personalization. Therefore, the establishment of the credit-based system with Chinese characteristics shall be started with the realistic foundation. It is because that "if a system is to be fully effective, it must make people believe that the system is their own." ${ }^{[13]}$ Any individual or group should first analyze and weigh the costbenefit, and then in a set they can only choose the one to maximize the net income, and that is the best system.

\section{WAY OF THINKING ON THE REFORM OF CREDIT- BASED SYSTEM WITH CHINESE CHARACTERISTICS: INSTITUTIONAL INNOVATION}

Douglass C. North believes that the system is "a game rule of the society, or more formally the constraints that are designed by human to constitute the interactive behavior of people. They consist of the formal rules (statute laws, common laws and rules.) and informal rules (conventions, codes of conduct and codes of conduct for self - restraint.) and the execution characteristics of the two." ${ }^{[14]}$ Therefore, the credit-based system with Chinese characteristics can be divided into the category of system research. It also has the basic elements of the system, and the continuous renewal and improvement of the system is the prerequisite of the survival of the system. The author focuses on the institutional innovation of credit-based system in China under the formal institutional framework.

\section{A. Independent Choice + Limited Choice: Perfecting the Elective System with Chinese Characteristics}

The elective system is the premise of credit-based system reform with Chinese characteristics. From the perspective of the development history of the elective system, the key to the question is to give students how much right to choose. Specifically, one is how much autonomy the national government and educational administration departments give to universities and students. Second is how much autonomy the university gives students. It seems that a reasonable solution is between no elective or complete elective and between no learning freedom and complete learning freedom. There are four main elective forms in American universities: the first is free elective; the second is semi-open elective; the third is major plus minor; the fourth is grouping elective ${ }^{[15]}$.
Therefore, under the conditions of "information asymmetry", "limited rationality" of students, and interaction nature between teaching and learning, the reform of credit-based system with Chinese characteristics shall not be introduced blindly. It shall be ensured to control the freedom of elective course while ensuring the establishment of the national curriculum. First, to increase the proportion and scope of elective courses, ensure the high quality of elective courses, and eliminate the "class for people"; Second, to establish standard and minor and double degree system to enhance the adaptability and diversity of talent cultivation. Third, to make a proper treatment to ensure that students have a complete knowledge and capability structure, and also have a greater personal freedom of learning. And a distinctive operation mode shall be established by gradually improving the independent choice of majors, teachers, courses, learning progress and the period of schooling.

\section{B. Class Tutor System + System of Counselors: Exploring the Tutor System Suitable for China's National Conditions}

The establishment of tutor system is the basis for the reform of credit-based system with Chinese characteristics. At present, the system of head teachers and counselors is commonly practiced in China's colleges. The main responsibilities are management and control to ensure the smooth graduation of students. This system has led to the phenomenon of "only teaching without educating people" in some China's colleges, therefore, which it is difficult to adapt to the needs of the reform of credit-based system. While drawing on the foreign successful tutor system, the key is to solve the basic responsibilities of class tutors; what qualifications a tutor should possess and what treatment the tutor should enjoy and other basic problems. The first step of the institutionalized and individualized class tutor system is to make sure the capable person work at the tutor position and set the criteria for the selection system. The second step is to combine the construction of class tutor team with tutors' personal development and improve the training and development system for tutors. The corresponding tutor training standard shall be formulated to make tutors' identity conversion from "knowledge authority" to "learning instructor". The third step is to implement "double selection system". According to the development requirements of students and the professional research field of a tutor, we implement the double selection system which embodies the principle of "intersubjectivity" of modern educational thought. The forth step is to introduce the performance appraisal system of class tutor. We shall clear incentives and rewards and punishment mechanisms to combine tutors' work with their performance. Therefore, the "class tutor system + system of counselors" is kept with the class system, which connect the relation between class tutors and counselors and is an ideal student management mode under the credit-based system. 
C. Class Teaching System + Course Class System:

Innovating the Learning Organization with Integration of Division and Combination

The credit-based system with Chinese characteristics should take into account the relationship between centralized management and self-management. Under the credit-based system, college students are enrolled into regular classes by their majors. The class has a clear faculty (department) ownership, and students' class is basically stable. They have common professional learning features. "Class group" has become a teaching unit for major required courses, which is conducive to the implementation of the "class group" teaching system. But when students are given greater freedom of independent choice, the mobility of student groups will increase. The students taught by some teachers may be students from different grades, majors and faculties (departments). Class system becomes the teaching unit of elective courses. The existence time of curriculum class is relatively short, and it is "disintegrated" with the completion of a course. During the study period, the students will be combined to some transient groups, such a transient and dynamic course learning group. In the process of interacting with different peer groups, there are more opportunities to contact different disciplines and professional fields. Therefore, we should combine the reality of our country, change the single class teaching system and innovate the student teaching organization form. We should guide students to downplay the concept of fixed class and improve the collective learning mode with integration of division and combination.

\section{Professional Registration Fee System + Course Credit Fee System: Establishing Credit Charging Management Model}

The credit charging system is a guarantee for the reform of credit-based system with Chinese characteristics. As stipulated in Notice of the State Development and Reform Commission on Further Strengthening the Management of Credit Charging System of Colleges and Universities, the credit charging system in colleges and universities must be submitted through the prescribed procedures. The tuition fee charged by the credit charging system shall not be higher than the total fee charged by the credit-based system. However, the document does not specify how to estimate the measurement standard of education cost and the unit price of credits. Some scholars think that the cost of education includes not only faculty salaries, student funds, administrative expenses, business expenses, maintenance costs, depreciation of fixed assets and other expenses to maintain normal operation of schools, but also the costs of nurturing teacher echelon, construction of discipline, profession and infrastructure construction, and the necessary capital expenditure focusing on the future development of school $^{[16]}$. It is obvious that this view does not take into account the characteristics of different types of universities. And that the influencing factors of educational cost accounting are rather complicated, and the measurement method and system are not perfect. In fact, the in-depth study and insufficient supply of credit charging system has cast a shadow on the budget of higher education. The credit charging system should take into account the characteristics of different types of universities and reflect the difference of educational cost of specialties (i.e. professional registration fee system), as well as show the difference between the pricing and charging of different courses in terms of credit cost (course credit fee system), and reflect the factors of market supply and demand. Therefore, it should be based on the educational cost accounting, taking into account the impact of supply and demand of teaching resources. We should reasonably establish the standard of credit charging system, and determine the proportion of professional registration fees and course credits tuition.

\section{E. Credit Authentication System + Credit Transfer System: Improving the Mutual Recognition Mechanism for Learning Outcomes}

Credit identification and transformation system are effective ways to promote the reform of credit-based reform with Chinese characteristics, because they are also the inherent characteristics of credit system itself, such as accumulation ability and negotiability. The western experience shows that the systematical implementation of credit recognition and transformation system depends on the government's macro control function and the exerting extent of main functions of colleges and universities. From the government level, although there are provisions of principles in the official documents encouraging credit identification and transformation, they are lack of elaborate top-level design and practical promoting measures. They are also lack of standards and guidance system rules of credit identification and transformation issued by the state or local governments. Therefore, the functions of the government shall be changed to establish and promulgate the overall framework and standard system, and provide the necessary guidance and support for the university to participate in credit identification and transformation. From the university level, a college is the subject of credit identification and transformation. The central premise is that there is common concept identification on credit identification and transformation among universities. Then, with the consensus, the cooperation intention is reached to determine the scope, standards and methods of credit identification and transformation. The key lies in system identification which shall form a binding and feasible system document. At the stage of "Internet + Education", credit identification and transformation are moving from physics classrooms to virtual classrooms, which urgently needs the transformation mechanism, standards and management methods of micro credit and traditional credit, and the establishment of a credit management system suitable for MOOCs development.

\section{CONCLUSION}

The key of the reform of college teaching management system lies not in the implementation of scholastic year system, credit-based system or credit system, but in what these systems to be implemented are. The credit-based system with Chinese characteristics shall be formed, changed and innovated in accordance with the political, economic and cultural background of our country. From focusing on simple 
transplantation of system to indigenous innovation of system, from mandatory system change to the induced institutional change mode, the process of localization of credit system shall not be rushed to be advanced but also shall be avoided form formalism. We shall explore a teaching management mode of modern university credit system suitable for China's national conditions and the popularization of higher education.

\section{REFERENCES}

[1] Deng Xinrong. Thoughts on Selection and Implementation of Credit System in Chinese Universities [J]. Journal of Technology College Education, 2009(6):58-60. 邓新荣.对我国高校学分制模式选择及实 施的思考 [J].理工高教研究,2009(6):58-60.

[2] Jiang Fugang, Zhang Baoqing. Reform and Prospect of Credit System [J]. Modern Education Science, 2008(1):97-99. 姜福刚,张宝庆.学分 制改革与展望[J].现代教育科学,2008(1):97-99.

[3] Song Zhanchun. Reality Contradiction of Credit System in China's Colleges [J]. Journal of Shenyang University, 2008(2):101-103. 宋占 春.我国高校学分制的现实矛盾 [J].沈阳大学学报,2008(2):101-103

[4] Yang Yan. Rethinking on Implementation of Credit System in Colleges[J]. Heilongjiang Researches on Higher Education, 2004(3):93-94. 杨燕. 对高校实施学分制的再思考 [J]. 黑龙江高教研 究,2004(3):93-94.

[5] Sun Zhengyu. Introduction to Philosophy[M]. Shenyang: Liaoning People's Publishing House, in 1998, Page 342. 孙正聿. 哲学通论[M]. 沈阳:辽宁人民出版社, 1998 年,第 342 页.

[6] Qian Mu, Chinese Political Success and Failure in Past Dynasties[M].Beijing: SDX Joint Publishing Company, in 2005, Page 2 of the preface. 钱穆, 中国历代政治得失[M]. 北京:生活读书新知三 联书店,2005 年,前言第 2 页.

[7] Wang Dingding. Basis of System Analysis: A Handout for the Era of Broadband Network [M].Beijing: Social Sciences Academic Press, in 2002, Page 38. 汪丁丁.制度分析基础:一个面向宽带网络时代的讲 义 $[\mathrm{M}]$.北京:社会科学文献出版社,2002 年,第 38 页.

[8] Franz.F. Frans Van Vught. Comparison of National Higher Education Policies[M]. translated by Wang Chengxu, etc. Hangzhou: Zhejiang Education Publishing House, in 2001, Page 414. 弗兰 斯·F. 范富格特.国家高等教育政策比较 $[\mathrm{M}]$.王承绪, 等译.杭州:浙 江教育出版社,2001 年,第 414 页.

[9] Feng Xiangdong. Deep Reform of Credit System Teaching System and Concept[J]. Journal of Higher Education,2003(6):59-63. 冯向东. 推行学分制教学制度与观念的深刻变革 [J]. 高等教育研 究,2003(6):59-63.

[10] Xiao Ruifeng. Curriculum Thought and Construction Strategy of Universities[J]. China Higher Education Research, 2009(6):79-80. 肖 瑞峰.大学的课程思想与建设策略[J].中国高教研究,2009(6):79-80.

[11] Publicity of Changing Majors Status of Outstanding Undergraduate Students in 2016-2017 School Year.[2016-09-21]. [1217-0715].http://aa.gzu.edu.cn/s/26/t/607/2b/f9/info76793.htm. 2016-2017 学年度优秀本科生校内转专业情况公示.[2016-09-21]. [1217-0715].http://aa.gzu.edu.cn/s/26/t/607/2b/f9/info76793.htm.

[12] Li Weiyan, Liu Haimin A study on Misunderstanding and Countermeasures in the Credit System Reform[J]. Journal of Higher Education,2005(1):74-77. 李伟言,柳海民. 学分制改革中的认识误区 及对策研究 [J].高等教育研究,2005(1):74-77.

[13] Harold Berman. Law and Religion[M]. translated by Liang Zhiping, SDX Joint Publishing Company, in 1991, Page 39. 伯尔曼.法律与宗 教[M].梁治平译,北京:生活·读书·新知三联书店,1991 年,第 39 页.

[14] Douglas. Nors. Structure and Change in Economic History[M]. Shanghai: Shanghai People's Publishing House, in 1994, Page 225226. 道格拉斯. 诺斯. 经济史中的结构与变迁 $[\mathrm{M}]$. 上海: 上海人民出 版社,1994 年,第 225-226 页.

[15] Wang Yue. Main Features of American College Credit System and Its Implications to China[J]. Education Exploration, 2010 (4) :156-157.
王玥.美国高校学分制的主要特点及其对我国的启示[J].教育探 索,2010 (4):156-157.

[16] Zhang Fengxia, Yang Huan and Wang Chunnian. Thoughts on Improving the Charge Management of Credit System in Colleges[J]. Economics and Management, 2006(3):91-93. 张凤霞，杨欢，王春 年.完善高校学分制收费管理的思考 [J].经济与管理,2006(3):91-93. 